\title{
Water storage in Eucalyptus urophylla progenies
}

\author{
Armazenamento de água em progênies de Eucalyptus urophylla \\ Laerte Scanavacca Júnior ${ }^{1}$ (1) , José Nivaldo Garcia² (1) \\ ${ }^{1}$ Embrapa Meio Ambiente - CNPMA, Jaguariúna, SP, Brasil \\ 2Escola Superior de Agricultura "Luiz de Queiroz" - ESALQ, Universidade de São Paulo - USP, Piracicaba, SP, Brasil
}

How to cite: Scanavacca Júnior, L., \& Garcia, J. N. (2021). Water storage in Eucalyptus urophylla progenies. Scientia Forestalis, 49(132), e3715. https://doi.org/10.18671/scifor.v49n132.10

\begin{abstract}
Eucalypts are the most planted hardwoods in the world with around 30 million ha; one of which is $E$. urophylla, which is also one of the most planted species in Brazil. The objective of this work was to study water storage in the stem of progenies and verify the influence of precipitation on soil and wood humidity, as well as planting density (spacing between trees) on the humidity and productivity of the progenies. To this end, 21 progenies were evaluated in three replications (one progeny per block) in a progeny test. The results show that the productivity and humidity of the progenies did not depend on rainfall or soil humidity. Planting density did not influence productivity of wood or soil humidity.
\end{abstract}

Keywords: Hydraulic conductance; Pearson's correlation; Soil humidity; Wood anatomy, Water storage in the stem.

\section{Resumo}

O eucalipto é a folhosa mais plantada no mundo com cerca de 30 milhões de ha, sendo uma delas o E. urophylla, que também é uma das mais plantadas no Brasil. O objetivo deste trabalho foi estudar o armazenamento de água no fuste de progênies e verificar a influência das precipitações na umidade do solo e da madeira, bem como a densidade de plantio (espaçamento entre árvores) na umidade e produtividade das progênies. Para tal, foram avaliadas 21 progênies em três repetições (uma progênie por bloco) em um teste de progênies. Os resultados mostram que a produtividade e umidade das progênies não dependem das precipitações nem da umidade do solo. A densidade de plantio não influenciou a produtividade nem a umidade da madeira ou solo.

Palavras-chave: Condutância hidráulica; Correlação de Pearson; Umidade do solo; Anatomia da madeira; Armazenamento de água no fuste.

\section{INTRODUCTION}

Eucalyptus is the most planted hardwood genus in the world, with approximately 30 million hectares, $90 \%$ of which are concentrated in nine species, being $E$. urophylla one of them, as it presents good productivity in any type of soil or climate, is easy to propagate by seeds or cuttings, produces well in the second rotation and is suitable for wide array of uses. In Brazil, 7.62 million hectares were planted with eucalypts in 2019, with E. urophylla being one of the most planted species (Indústria Brasileira de Árvores, 2020; Payn et al., 2015; Scanavaca Júnior \& Garcia, 2021). In Brazil, E. urophylla does not adapt to the semi-arid region, where the precipitation is less than $800 \mathrm{~mm}$; while the provenances introduced in Brazil are adapted to areas with more than $1000 \mathrm{~mm}$ of annual precipitation. The provenance which might adapt to the semi-arid region is from Wetar Island or E. wetarensis (Reclassification of provenance,

Financial support: None.

Conflict of interest: Nothing to declare.

Corresponding author: laerte.scanavaca@gmail.com

Received: 19 May 2021

Accepted: 6 August 2021

Editor: Mauro Valdir Schumacher.

(c) (i) This is an Open Access article distributed under the terms of the Creative Commons Attribution License, which permits unrestricted use,

cC) distribution, and reproduction in any medium, provided the original work is properly cited. 
Pryor et al., 1995), but there are other Eucalyptus species more suitable for such a climate, like E. camaldulensis, E. brassiana, etc.

The stems of the eucalypts have four basic functions: 1) transport of water and nutrients (xylem and phloem); 2) mechanical support of the crown (cellulose, hemicelluloses, and lignin; 3) storage of water (in the $65 \%$ fibers, $17 \%$ vessels and $18 \%$ parenchyma); 4 ) prevention of pest and disease attacks (mainly through the extractives, which are 5\%). The composition and proportion of these constituents varies with the species and age of the plant due to genetic and environmental influences. The percentage of extractives and lignin increases with age, while the proportion of holocellulose decreases; the proportion of vessels and parenchyma (rays) increases, while fibers decrease with age. The wall thickness and length of fibers, vessels and rays increase from the pith to the bark in the radial direction. As the tree grows from the outside in, new layers of cells are added to the tree. The youngest tissues follow the apical growth of the tree, so that the cells formed first go from the base to the top of the tree, that is, the oldest and thinnest vessels are at the apex of the tree, while the newer ones, with larger diameters and lengths, are at the base; in the same way the radii and fibers are arranged so that their diameters increase from the top to the base of the tree. In this way, the narrowest vessels, with the smallest diameter of the lumens, are in the highest parts of the trees, being able to withstand greater tensions in water transport.

According to the stress-cohesion theory, xylem water is constantly under stress, moving from the roots to the leaves of trees. This tension can overcome the cohesive forces that bind the water molecules, resulting in the formation of air bubbles which, when expanding form, a void, breaking the cohesion forces, which will cause cavitation, interrupting the rise of water through this channel and hence the rate of photosynthesis. The storage of water in the stem is important to maintain the plant's water balance. The removal of water from the stem during the day and the replenishment of these reserves at night is a dynamic process. The water stored in the cellular cavities of the stem can supply six to $28 \%$ of the tree's daily water requirements (Hao et al., 2013; Zweifel et al., 2007).

There are three mechanisms by which the water stored in the stem of trees can be released for the physiological processes of the plant: (1) capillary storage where water is stored mainly in the lumen of dead fibers (heartwood or pith); this water moves between the cells without energy cost; (2) elastic storage, water is located in the symplast of living cells, like the radial parenchyma cells, located in the sapwood, this water moves with energy expenditure; and (3) cavitation release, this water comes from the phloem to restore the connectivity of the cavitation water columns, with energy expenditure (Knipfer et al., 2019).

The objective of this study was to verify the adaptive strategies of water deficit in E. urophylla, which lead to adaptation to diverse climatic environments. The following hypotheses were raised: 1) soil and wood humidity accompany the precipitations; 2) larger diameter progenies have a higher percentage of water in the wood; 3 ) lower planting densities have a higher percentage of water in the soil; 4) soil humidity is the main factor that determines progeny productivity.

\section{MATERIAL AND METHODS}

\section{Genetic material, climatological data and experiment layout}

This material is part of the Basic Population Cooperative Program (PCPN), created by the Institute for Forestry Research and Studies (IPEF) in 2008, whose objective was to install populations with a broad genetic base and to recombine them. For E. urophylla, 167 progenies were used. This test was installed in several bioclimatic regions of Brazil, with Anhembi, SP being one of these locations.

The material was installed in Anhembi ( $22^{\circ} 40$ 'S; $48^{\circ} 10^{\prime}$ W $\mathrm{W}$ and $455 \mathrm{~m}$ above sea level), on flat ground. The experiment was installed in a Dystrophic Yellow Latosol, containing 5 to $8 \%$ of clay, 2 to $3 \%$ of silt and 89 to $93 \%$ of sand. Soil field capacity lies between 5 and $13 \%$. The $\mathrm{pH}$ varies from 4.6 to 5.8 depending on the depth; it is deficient in macro and micronutrients. 
The climate, according to Köppen's classification, is Cwa, with hot, rainy summers and moderately cold, dry winters. The occurrence of frosts is rare. The average annual temperature is $23^{\circ} \mathrm{C}$, and the average temperature of the coldest and hottest months is $17.1^{\circ} \mathrm{C}$ and $23.7^{\circ} \mathrm{C}$, respectively. The minimum and maximum temperatures are, respectively, $5^{\circ} \mathrm{C}$ and $34^{\circ} \mathrm{C}$. Mean annual precipitation is $1,100 \mathrm{~mm}$ and the annual water deficit is $20 \mathrm{~mm}$ (Empresa Brasileira de Pesquisa Agropecuária, 2018; Universidade de São Paulo, 2020).

The experiment was installed in December 2009, in randomized complete blocks with 167 progenies, four replications, linear plots with six plants per plot, in a spacing of $3 \mathrm{~m} \times 2 \mathrm{~m}$. In a progeny test, 21 progenies were selected with three replications, one per block. The selection was made with the expectation of thinning at the end of the experiment to evaluate the physical and mechanical properties of the wood; therefore, the selection went from the bottom and the best tree in the plot was not selected. Meteorological data were provided by ESALQ.

\section{Soil humidity}

The experiment was evaluated every three months for 18 months (04/26/17 to 11/21/18), spanning six climatic seasons. Soil samples were taken in open areas, intermediate areas and closed areas within the experiment, at depths from 0 to 10 and 20 to $30 \mathrm{~cm}$, with two replications per block, to measure the percentage of soil moisture in each season of the year, using an increment borer with a capacity of 100 grams. At one station, soil samples were not collected because it rained in torrents, making collection impossible on the assessment days.

The areas were classified as open, intermediate, or closed depending on planting density. Areas that suffered the highest percentage of thinning and had the lowest planting density within the experiment and were classified as open areas. Closed areas were those that did not undergo any thinning and presented the original planting density of the experiment ( $3 \mathrm{~m} \times 2 \mathrm{~m}$ spacing). Intermediate areas had intermediate tree densities between these two extremes.

To measure tree moisture, wood fillets were extracted using a motorized borer with a power HP and an increment borer with $20 \mathrm{~mm}$ diameter and $20 \mathrm{~cm}$ length. The trees were drilled until reaching the pith, the heights varied from 130 to $170 \mathrm{~cm}$ above the ground. After the extraction of the wood fillet, the holes were covered with wooden coins of the same diameter as the borer to reduce or avoid the risk of attack by pests or diseases.

The fillets were identified and stored in a plastic bag and packed in Styrofoam. On the same day, the fillets were divided into several segments of approximately two centimeters in length, properly identified and weighed on a digital scale with a precision of $0.01 \mathrm{~g}$.

After weighing, the fillets were placed in an oven at $103^{\circ} \mathrm{C} \pm 2{ }^{\circ} \mathrm{C}$ until constant weight. After stabilization of the weights, the fillets were weighed again to calculate the moisture. Due to their indistinct color and weight, the first segment (closest to the center of the tree) was considered medulla. The last segment, closer to the bark was sapwood. The remaining segments of the central part were considered heartwood. Heartwood moisture was considered as being the arithmetic mean of the segments of these central threads.

The moisture of each segment of wood, as well as the soil samples were calculated using the Equation [(WW - DW) / DW] * 100. Where: WW is the wet weight of the sample (g); and DW is the dry weight of the sample (g).

\section{Basic density (Bb)}

The basic density was determined after the sixth evaluation (15/01/2019), when the trees were cut. A $2 \mathrm{~cm} \times 2 \mathrm{~cm} \times 3 \mathrm{~cm}$ cube was removed from the heartwood of tree. The wooden cubes were saturated to a constant weight. After saturation, the samples were measured with a $0.01 \mathrm{~mm}$ precision caliper. After these procedures, the wooden cubes were placed in an oven at $103{ }^{\circ} \mathrm{C} \pm 2{ }^{\circ} \mathrm{C}$ until constant weight. After weight stabilization, the wooden cubes were weighed on a scale with a precision of $0.01 \mathrm{~g}$. Basic density is the ratio between dry mass and saturated volume $\left(\mathrm{kg} \mathrm{m}^{-3}\right)$. 


\section{Diameter at breast height (DBH) (cm)}

The DBH was measured at approximately $1.30 \mathrm{~m}$ from the ground, in all plots, using a dendrometric caliper with a precision of $1 \mathrm{~cm}$; except for one season when it rained, making the operation impossible.

\section{Statistical analysis}

Statistical analyses were performed using SAS 9.3 statistical package using Proc Glimmix procedure and Pearson correlation using Proc Corr. Data normality was tested using Proc Univariate. The level of significance was set at 5\% probability.

\section{RESULTS AND DISCUSSION}

Table 1 - Maximum and minimum temperature and accumulated precipitation by season in 2017 and 2018 in Anhembi.

\begin{tabular}{ccccc}
\hline \multirow{2}{*}{ Season } & \multicolumn{2}{c}{ Temperature $\left({ }^{\circ} \mathbf{C}\right)$} & & Precipitation \\
\cline { 2 - 3 } & Maximum & Minimum & & accumulated $(\mathbf{m m})$ \\
Summer & 35.66 & 17.27 & & $535.74^{\star}$ \\
Autumn & 31.24 & 10.51 & & 420.64 \\
Winter & 32.58 & 8.21 & 144.73 \\
Spring & 35.96 & 13.26 & 584.47 \\
Summer & 35.36 & 17.19 & 516.33 \\
Autumn & 32.23 & 8.03 & $50.94^{*}$ \\
Winter & 33.77 & 6.10 & $22.32^{\star *}$ \\
Spring & 35.45 & 13.22 & 43.02 \\
Mean & 34.03 & 11.72 & 289.77 \\
Standard Deviation & 1.83 & 4.21 & 246.78 \\
Variation Coefficient & 1.72 & 9.82 & \\
\hline
\end{tabular}

* Soil moisture, DBH and wood moisture were not evaluated. ** Soil moisture and DBH were not evaluated.

\section{Climatological data}

Climatic data for Anhembi were provided by ESALQ/USP. Data from 2017 and 2018 were used. Temperatures varied little, but precipitation varied considerably according to the coefficient of variation (CV) and standard deviation (SD) (Table 1). There was no correlation between precipitation and wood humidity $(0.2333 p=0.6564)$, soil humidity $(010 \mathrm{~cm}:-0.4822$ $p=0.4107$; and 20 to $30 \mathrm{~cm}:-0.4956 p=0.3959)$ or DBH $(-0.5703 p=0.3154)$.

Table 2 - Average soil moisture in the five seasons by area opening and depth.

\begin{tabular}{|c|c|c|c|}
\hline Depth & Closed area & Intermediate area & Open area \\
\hline & & Autumn (26/04/17) & \\
\hline 0 a 10 & 7.32 & 8.93 & 7.75 \\
\hline \multirow[t]{2}{*}{20 a 30} & 8.04 & 8.60 & 8.02 \\
\hline & & Winter (16/08/17) & \\
\hline 0 a 10 & 11.94 & 10.22 & 9.03 \\
\hline \multirow[t]{2}{*}{20 a 30} & 11.11 & 10.56 & 9.88 \\
\hline & & Spring $(24 / 11 / 17)$ & \\
\hline 0 a 10 & 62.19 & 63.26 & 69.82 \\
\hline \multirow[t]{2}{*}{20 a 30} & 63.72 & 69.92 & 73.48 \\
\hline & & Summer $(26 / 02 / 18)$ & \\
\hline 0 a 10 & 65.84 & 69.25 & 64.67 \\
\hline \multirow[t]{2}{*}{20 a 30} & 68.85 & 69.32 & 73.47 \\
\hline & & Spring $(21 / 11 / 18)$ & \\
\hline 0 a 10 & 66.29 & 64.70 & 60.04 \\
\hline 20 a 30 & 69.09 & 69.09 & 69.75 \\
\hline
\end{tabular}




\section{Soil humidity}

Data were statistically analyzed related to planting density or gap size (opening by thinning or death of progenies).

There were no statistical differences between soil humidity related to planting density or depth at any time of year. The soil has a sandy texture whose field capacity (FC) is between 5 and $13 \%$. In all seasons, the 20 to $30 \mathrm{~cm}$ depth layer was slightly wetter than the top layer, except in the intermediate area in autumn and in the closed area in winter (Table 2). After water drainage, the deeper layers become wetter than the upper layers (Empresa Brasileira de Pesquisa Agropecuária, 2018; Melo Neto et al., 2017). Assuming FC was 5\%, all samples were above this level; but if we consider $13 \%$ FC, all autumn and winter evaluations were below FC. At a FC of 13\% water would still be percolating, thus, the lower layer should have a higher percentage of humidity than the upper layer, in the same soil profile. If the $\mathrm{FC}$ were $5 \%$, the water would have already stopped its movement and the humidity percentages should be close, but the humidity could be higher in any layer, due to the variability of the soil (higher clay content, smaller pore diameters, etc.), as found in the present study.

Magalhães et al. (2018), working on Dystrophic Yellow Latosol, in a livestock and forest cropping system at three spacings, did not find statistical differences for soil humidity related to spacing. Melo Neto et al. (2017) working with E. urophylla $\times$ grandis related to spacing had the same result and so did Liu et al. (2017) when considering age.

In this study, in the dry seasons (autumn and winter), soil humidity was around $10 \%$. In the rainy seasons (spring and summer), the humidity was above $60 \%$. Somehow the trees compensated for the difference in soil humidity and presented a stem with low humidity fluctuations. There are several mechanisms used by eucalyptus species to maintain humidity in the wood and, consequently, productivity; among these stand out the deepening of the root system; more efficient use of water; reduction of photosynthesis rate, etc. (Bourne et al., 2017; Zhang et al., 2016).

Soil water availability did not affect wood humidity at any time. The maximum amplitude, from one season to another in the six measurements, was $8.66 \%$ in stem humidity (Tables 4 to 9). This was much smaller than the range of soil humidity, which was 10 times wetter in the rainy seasons (7.32\% in autumn and $73.48 \%$ in spring) (Table 2 ).

Table 3 - Correlation of soil moisture with wood moisture, Diameter at Chest Height (DCH) and Basic density (Bd).

\begin{tabular}{cccccc}
\hline Variables & $\mathbf{t}$ value & Probability $\mathbf{~}$ & Variables & t value & Probability $\mathbf{~}$ \\
\hline & Soil 1a & $\mathbf{0} \mathbf{a} \mathbf{1 0} \mathbf{c m}$ & & Soil 3b & $\mathbf{2 0} \mathbf{a} \mathbf{3 0} \mathbf{c m}$ \\
\hline Pith1 & 0.1296 & 0.3115 & Pith3 & 0.0784 & 0.5412 \\
Heartwood1 & 0.0819 & 0.5234 & Heartwood3 & 0.1457 & 0.2546 \\
Sapwood1 & 0.0038 & 0.9764 & Sapwood3 & 0.2103 & 0.0981 \\
Average1 & 0.0939 & 0.4641 & Average3 & 0.1752 & 0.1696 \\
DBH1 & -0.0590 & 0.6458 & DBH3 & -0.1851 & 0.1464 \\
Bb & -0.0200 & 0.8763 & Bb & -0.1716 & 0.1788 \\
\hline & Soil 1b & $\mathbf{2 0 ~ a ~ 3 0 c m ~}$ & & Soil 4a & $\mathbf{0} \mathbf{a} \mathbf{1 0} \mathbf{c m}$ \\
\hline Pith1 & 0.1037 & 0.4186 & Pith4 & -0.0753 & 0.5575 \\
Heartwood1 & 0.0637 & 0.6199 & Heartwood4 & 0.0022 & 0.9864 \\
Sapwood1 & -0.0354 & 0.7829 & Sapwood4 & -0.0309 & 0.8103 \\
Average1 & 0.0581 & 0.6513 & Average4 & -0.0541 & 0.6737 \\
DBH1 & -0.0428 & 0.7391 & DBH4 & 0.0414 & 0.7474 \\
Bb & 0.0278 & 0.8289 & Bb & 0.0721 & 0.5747 \\
\hline
\end{tabular}


Table 3 - Continued...

\begin{tabular}{|c|c|c|c|c|c|}
\hline Variables & t value & Probability $t$ & Variables & t value & Probability $\mathrm{t}$ \\
\hline & Soil 2a & 0 a $10 \mathrm{~cm}$ & & Soil 4b & 20 a $30 \mathrm{~cm}$ \\
\hline Pith2 & -0.1252 & 0.3282 & Pith4 & 0.0651 & 0.6121 \\
\hline Heartwood2 & -0.1516 & 0.2357 & Heartwood4 & 0.0231 & 0.8574 \\
\hline Sapwood2 & -0.1338 & 0.2959 & Sapwood4 & -0.0007 & 0.9959 \\
\hline Average2 & -0.1651 & 0.1960 & Average4 & 0.0439 & 0.7325 \\
\hline $\mathrm{DBH} 2$ & 0.1111 & 0.3859 & $\mathrm{DBH} 4$ & -0.1629 & 0.2022 \\
\hline \multirow[t]{2}{*}{$\mathrm{Bb}$} & 0.1786 & 0.1613 & $\mathrm{Bb}$ & -0.2415 & 0.0565 \\
\hline & Soil 2b & 20 a $30 \mathrm{~cm}$ & & Soil $6 a$ & 0 a $10 \mathrm{~cm}$ \\
\hline Pith2 & -0.1285 & 0.3156 & Pith6 & -0.2619 & 0.0381 * \\
\hline Heartwood2 & -0.1559 & 0.2225 & Heartwood6 & -0.3292 & $0.0084 * \star$ \\
\hline Sapwood2 & -0.1181 & 0.3566 & Sapwood6 & 0.3055 & $0.0149 *$ \\
\hline Average2 & -0.1631 & 0.2015 & Average6 & -0.3721 & $0.0027 * \star$ \\
\hline $\mathrm{DBH} 2$ & 0.1031 & 0.4212 & DBH6 & 0.0860 & 0.5029 \\
\hline \multirow[t]{2}{*}{$\mathrm{Bb}$} & 0.2022 & 0.1120 & $\mathrm{Bb}$ & 0.2298 & 0.0700 \\
\hline & Soil 3a & 0 a $10 \mathrm{~cm}$ & & Soil $\mathbf{6 b}$ & 20 a $30 \mathrm{~cm}$ \\
\hline Pith3 & 0.0868 & 0.4989 & Pith6 & 0.1256 & 0.3280 \\
\hline Heartwood3 & 0.1452 & 0.2562 & Heartwood6 & 0.1820 & 0.1534 \\
\hline Sapwood3 & 0.2111 & 0.0968 & Sapwood6 & 0.2515 & $0.0468^{*}$ \\
\hline Average3 & 0.1801 & 0.1579 & Average6 & 0.2281 & 0.0722 \\
\hline DBH3 & -0.1886 & 0.1388 & DBH6 & -0.0606 & 0.6369 \\
\hline $\mathrm{Bb}$ & -0.2362 & 0.0623 & $\mathrm{Bb}$ & -0.1738 & 0.1733 \\
\hline
\end{tabular}

Soil $1^{\mathrm{a}}=$ camada de 0 a $10 \mathrm{~cm} ; \mathrm{b}=$ camada de 20 a $30 \mathrm{~cm}$; índice 1 = Primeira avaliação, 2 = segunda avalição, etc.; $\mathrm{DBH}=$ Diameter breast height; $\mathrm{Bb}=$ Basic density.

There was a correlation between soil humidity and wood humidity in the sixth evaluation (spring, 11/21/18), the season with one of the lowest rainfalls during the experiment evaluation $(43.02 \mathrm{~mm}$ ) (Table 1). The soil was moist and the progenies removed water from the soil for immediate consumption in the photosynthesis process, with the sapwood showing a positive correlation with soil humidity at both depths, while the other compartments showed a negative correlation, that is, the soil water was insufficient for the photosynthesis rates used by the trees, so that complementation with water from the heartwood and pith was necessary; therefore the correlations were positive for the sapwood and negative for the heartwood and pith. The fact that there was no correlation between the humidity content of wood and soil in the other evaluations means that the progenies were getting water from deeper layers, that is, they did not depend on precipitation (Table 3).

\section{Natural wood moisture}

Six wood humidity assessments were carried out, one in each season, three in 2017 and three in 2018. The normality tests showed that the data came from a normally distributed population, therefore, they were analyzed as being parametric. 
Table 4 - Natural wood moisture per progeny and Tukey test at 5\% probability, average of three trees, on 04/26/2017 (Autumn).

\begin{tabular}{ccccc}
\hline Progeny & Pith & Heartwood & Sapwood & Average \\
\hline 32 & 139.02 & $134.21 \mathrm{abcde}$ & 128.54 & 133.92 \\
33 & 127.99 & $121.53 \mathrm{bcdef}$ & 88.82 & 112.78 \\
51 & 156.80 & $160.23 \mathrm{a}$ & 102.07 & 139.70 \\
52 & 146.77 & $156.69 \mathrm{ab}$ & 120.19 & 141.22 \\
53 & 114.66 & $142.17 \mathrm{abcd}$ & 115.78 & 124.21 \\
54 & 124.76 & $118.12 \mathrm{cdef}$ & 102.71 & 115.20 \\
59 & 150.60 & $142.30 \mathrm{abcd}$ & 120.82 & 137.90 \\
75 & 146.39 & $130.63 \mathrm{abcdef}$ & 88.67 & 121.90 \\
82 & 115.61 & $133.38 \mathrm{abcdef}$ & 101.06 & 116.68 \\
85 & 106.18 & $106.13 \mathrm{def}$ & 105.77 & 106.03 \\
88 & 155.44 & $143.81 \mathrm{abc}$ & 122.69 & 140.65 \\
91 & 107.44 & $138.93 \mathrm{abcde}$ & 121.93 & 122.77 \\
92 & 143.74 & $146.96 \mathrm{abc}$ & 121.09 & 137.27 \\
94 & 122.99 & $119.41 \mathrm{cdef}$ & 108.51 & 116.97 \\
101 & 118.33 & $128.14 \mathrm{abcdef}$ & 115.30 & 120.59 \\
108 & 126.85 & $122.80 \mathrm{bcdef}$ & 89.78 & 113.14 \\
125 & 100.83 & $103.22 \mathrm{ef}$ & 126.75 & 110.27 \\
133 & 133.32 & $141.99 \mathrm{abcd}$ & 106.24 & 127.18 \\
137 & 133.24 & $137.12 \mathrm{abcde}$ & 93.98 & 121.45 \\
138 & 101.99 & $97.85 \mathrm{f}$ & 76.17 & 92.01 \\
142 & 127.55 & $118.19 \mathrm{cdef}$ & 96.80 & 114.18 \\
Mean & 128.59 & 130.66 & 107.32 & 122.19 \\
Standard deviation & 23.36 & 22.29 & 24.18 & 18.92 \\
\hline
\end{tabular}

Means followed by the same letter do not differ by the Tukey test at $5 \%$.

Table 5 - Natural wood moisture per progeny and Tukey test at 5\% probability, average of three trees, on 08/16/2017 (winter).

\begin{tabular}{|c|c|c|c|c|}
\hline Progeny & Pith & Heartwood & Sapwood & Average \\
\hline 32 & 135.14 & 136.61 & $124.09 a b$ & $131.95 \mathrm{abcd}$ \\
\hline 33 & 120.25 & 123.49 & $99.68 \mathrm{abc}$ & $114.47 \mathrm{bcd}$ \\
\hline 51 & 163.86 & 157.85 & 103.17 abc & $141.63 a b$ \\
\hline 52 & 156.52 & 146.39 & $114.49 a b c$ & $139.13 a b$ \\
\hline 53 & 146.52 & 139.48 & $102.66 \mathrm{abc}$ & $129.55 \mathrm{abcd}$ \\
\hline 54 & 134.76 & 128.93 & $82.77 \mathrm{c}$ & $115.48 \mathrm{abcd}$ \\
\hline 59 & 141.95 & 146.03 & $129.35 \mathrm{a}$ & $139.11 \mathrm{ab}$ \\
\hline 75 & 131.97 & 126.21 & $98.53 a b c$ & $118.91 \mathrm{abcd}$ \\
\hline 82 & 144.72 & 143.93 & 105.95 abc & $131.53 \mathrm{abcd}$ \\
\hline 85 & 112.32 & 104.96 & $86.66 \mathrm{c}$ & $101.31 \mathrm{~d}$ \\
\hline 88 & 146.38 & 142.24 & 93.68 bc & $127.44 \mathrm{abcd}$ \\
\hline 91 & 141.83 & 139.95 & $125.01 \mathrm{ab}$ & $135.60 a b$ \\
\hline 92 & 157.47 & 157.98 & $126.20 \mathrm{ab}$ & $147.22 \mathrm{a}$ \\
\hline 94 & 120.78 & 121.14 & $97.51 \mathrm{abc}$ & $113.14 \mathrm{bcd}$ \\
\hline 101 & 128.76 & 138.97 & $104.09 \mathrm{abc}$ & $123.94 \mathrm{abcd}$ \\
\hline 108 & 129.08 & 118.17 & $83.91 \mathrm{c}$ & $110.38 \mathrm{bcd}$ \\
\hline 125 & 106.50 & 102.54 & 101.42 abc & $103.48 \mathrm{~cd}$ \\
\hline 133 & 146.36 & 149.24 & $106.88 \mathrm{abc}$ & $134.16 \mathrm{abc}$ \\
\hline 137 & 148.34 & 136.55 & $98.65 a b c$ & $127.84 \mathrm{abcd}$ \\
\hline 138 & 101.24 & 105.12 & $96.26 \mathrm{abc}$ & $100.87 d$ \\
\hline 142 & 140.34 & 121.98 & $104.43 \mathrm{abc}$ & $122.25 \mathrm{abcd}$ \\
\hline Mean & 135.96 & 132.75 & 104.07 & 124.26 \\
\hline Standard deviation & 24.41 & 24.55 & 18.84 & 18.77 \\
\hline
\end{tabular}

Means followed by the same letter do not differ by the Tukey test at $5 \%$. 
Table 6 - Natural wood moisture per progeny and Tukey test at 5\% probability, average of three trees, on 11/24/2017 (Spring).

\begin{tabular}{ccccc}
\hline Progeny & Pith & Heartwood & Sapwood & Average \\
\hline 32 & 141.20 & $132.66 \mathrm{abcde}$ & 114.40 & $129.42 \mathrm{abcd}$ \\
33 & 116.71 & $115.05 \mathrm{cde}$ & 99.07 & $110.28 \mathrm{bcde}$ \\
51 & 147.08 & $157.62 \mathrm{a}$ & 101.17 & $135.29 \mathrm{ab}$ \\
52 & 153.87 & $142.38 \mathrm{abc}$ & 103.03 & $133.10 \mathrm{abc}$ \\
53 & 104.39 & $153.24 \mathrm{ab}$ & 116.54 & $124.72 \mathrm{abcde}$ \\
54 & 110.82 & $123.59 \mathrm{abcde}$ & 79.91 & $104.77 \mathrm{cde}$ \\
59 & 134.41 & $139.87 \mathrm{abcd}$ & 114.54 & $129.61 \mathrm{abcd}$ \\
75 & 140.20 & $128.69 \mathrm{abcde}$ & 89.86 & $119.58 \mathrm{abcde}$ \\
82 & 125.06 & $135.35 \mathrm{abcde}$ & 99.49 & $119.97 \mathrm{abcde}$ \\
85 & 107.46 & $101.80 \mathrm{e}$ & 95.80 & $101.69 \mathrm{de}$ \\
88 & 155.71 & $151.98 \mathrm{ab}$ & 88.12 & $131.93 \mathrm{abcd}$ \\
91 & 111.53 & $141.64 \mathrm{abc}$ & 107.52 & $120.23 \mathrm{abcde}$ \\
92 & 161.65 & $151.99 \mathrm{ab}$ & 113.02 & $142.22 \mathrm{a}$ \\
94 & 137.06 & $120.54 \mathrm{bcde}$ & 96.62 & $118.07 \mathrm{abcde}$ \\
101 & 125.17 & $138.77 \mathrm{abcd}$ & 112.76 & $125.57 \mathrm{abcde}$ \\
108 & 121.18 & $126.67 \mathrm{abcde}$ & 90.36 & $112.73 \mathrm{abcde}$ \\
125 & 113.12 & $105.34 \mathrm{de}$ & 91.44 & $103.30 \mathrm{cde}$ \\
133 & 144.92 & $144.40 \mathrm{abc}$ & 93.33 & $127.55 \mathrm{abcd}$ \\
137 & 147.53 & $139.74 \mathrm{abcd}$ & 94.76 & $127.34 \mathrm{abcd}$ \\
138 & 94.71 & $101.66 \mathrm{e}$ & 90.50 & $95.62 \mathrm{e}$ \\
142 & 136.15 & $128.69 \mathrm{abcde}$ & 102.46 & $122.43 \mathrm{abcde}$ \\
Mean & 129.30 & 132.46 & 99.75 & 120.74 \\
Standard deviation & 29.85 & 21.89 & 17.16 & 17.38 \\
\hline
\end{tabular}

Means followed by the same letter do not differ by the Tukey test at $5 \%$.

Table 7 - Natural wood moisture per progeny and Tukey test at 5\% probability, average of three trees, on 02/26/2018 (Summer).

\begin{tabular}{|c|c|c|c|c|}
\hline Progeny & Pith & Heartwood & Sapwood & Average \\
\hline 32 & 144.76 & 129.97 abcde & 111.51 & 128.75 \\
\hline 33 & 121.53 & 119.29 bcde & 102.14 & 114.32 \\
\hline 51 & 137.62 & $152.21 a b$ & 94.85 & 128.23 \\
\hline 52 & 114.93 & $142.85 \mathrm{abc}$ & 107.38 & 121.72 \\
\hline 53 & 145.74 & 132.61 abcde & 89.8 & 122.72 \\
\hline 54 & 105.24 & 118.24 bcde & 74.73 & 99.41 \\
\hline 59 & 128.58 & $136.46 \mathrm{abcd}$ & 71.78 & 112.28 \\
\hline 75 & 130.29 & 122.71 abcde & 81.33 & 111.44 \\
\hline 82 & 136.52 & $135.78 \mathrm{abcd}$ & 70.97 & 114.43 \\
\hline 85 & 106.35 & $105.88 \mathrm{de}$ & 89.06 & 100.43 \\
\hline 88 & 143.70 & 131.09 abcde & 102.46 & 125.75 \\
\hline 91 & 118.79 & $139.18 \mathrm{abcd}$ & 119.09 & 125.68 \\
\hline 92 & 147.46 & $153.25 \mathrm{a}$ & 116.16 & 138.96 \\
\hline 94 & 119.71 & 115.31 cde & 93.47 & 109.50 \\
\hline 101 & 117.90 & 124.99 abcde & 103.61 & 115.50 \\
\hline 108 & 82.49 & 119.23 bcde & 88.06 & 96.60 \\
\hline 125 & 99.11 & $106.04 \mathrm{de}$ & 86.46 & 97.20 \\
\hline 133 & 149.00 & 127.63 abcde & 88.8 & 121.81 \\
\hline 137 & 144.52 & 132.63 abcde & 90.85 & 122.67 \\
\hline 138 & 101.14 & $101.64 \mathrm{e}$ & 87.57 & 96.78 \\
\hline 142 & 136.64 & 112.01 cde & 110.17 & 119.61 \\
\hline Mean & 125.33 & 126.62 & 94.30 & 115.42 \\
\hline Standard deviation & 28.44 & 19.72 & 23.57 & 17.40 \\
\hline
\end{tabular}

Means followed by the same letter do not differ by the Tukey test at $5 \%$. 
Table 8 - Natural wood moisture per progeny, average of three trees, on 06/21/2018 (Winter).

\begin{tabular}{|c|c|c|c|c|}
\hline Progeny & Pith & Heartwood & Sapwood & Average \\
\hline 32 & 149.33 & 132.4 & 115.11 & 132.30 \\
\hline 33 & 110.37 & 124.14 & 95.96 & 110.16 \\
\hline 51 & 83.94 & 82.80 & 59.03 & 75.28 \\
\hline 52 & 130.06 & 131.21 & 107.68 & 122.98 \\
\hline 53 & 104.47 & 133.92 & 114.62 & 117.67 \\
\hline 54 & 154.57 & 151.48 & 115.61 & 140.55 \\
\hline 59 & 125.77 & 129.83 & 97.33 & 117.65 \\
\hline 75 & 121.59 & 116.18 & 93.74 & 110.50 \\
\hline 82 & 131.11 & 132.29 & 102.51 & 121.97 \\
\hline 85 & 126.26 & 127.25 & 98.13 & 117.21 \\
\hline 88 & 128.27 & 137.52 & 109.95 & 125.25 \\
\hline 91 & 140.81 & 134.23 & 140.31 & 138.45 \\
\hline 92 & 138.57 & 144.13 & 109.29 & 130.66 \\
\hline 94 & 124.39 & 119.68 & 85.41 & 109.83 \\
\hline 101 & 119.03 & 108.72 & 104.48 & 110.74 \\
\hline 108 & 118.45 & 121.79 & 80.88 & 107.04 \\
\hline 125 & 119.62 & 116.03 & 89.83 & 108.49 \\
\hline 133 & 120.46 & 114.15 & 84.53 & 106.38 \\
\hline 137 & 128.82 & 126.03 & 83.51 & 112.79 \\
\hline 138 & 109.28 & 114.01 & 76.55 & 99.95 \\
\hline 142 & 135.60 & 135.20 & 97.13 & 122.64 \\
\hline Mean & 126.80 & 125.38 & 99.18 & 116.12 \\
\hline Standard deviation & 34.00 & 25.93 & 27.69 & 25.34 \\
\hline
\end{tabular}

Table 9 - Natural wood moisture per progeny and Tukey test at 5\% probability, average of three trees, on $11 / 21 / 2018$ (Spring).

\begin{tabular}{|c|c|c|c|c|}
\hline Progeny & Pith & Heartwood & Sapwood & Average \\
\hline 32 & 124.04 & 134.13 & $137.98 \mathrm{a}$ & 132.05 \\
\hline 33 & 119.13 & 109.20 & 99.72 bcde & 109.35 \\
\hline 51 & 115.29 & 128.43 & 104.18 abcde & 115.96 \\
\hline 52 & 115.30 & 131.40 & $118.40 a b c$ & 121.70 \\
\hline 53 & 129.81 & 125.10 & 93.05 bcde & 115.99 \\
\hline 54 & 160.99 & 147.00 & $118.59 \mathrm{abc}$ & 142.19 \\
\hline 59 & 140.55 & 129.33 & 97.48 bcde & 122.45 \\
\hline 75 & 84.86 & 111.66 & 92.36 bcde & 96.30 \\
\hline 82 & 135.55 & 125.05 & 93.96 bcde & 118.19 \\
\hline 85 & 132.61 & 126.68 & 96.90 bcde & 118.73 \\
\hline 88 & 131.85 & 112.55 & 81.44 cde & 108.61 \\
\hline 91 & 109.72 & 130.05 & $112.54 \mathrm{abcd}$ & 117.44 \\
\hline 92 & 130.13 & 134.06 & $125.02 \mathrm{ab}$ & 129.74 \\
\hline 94 & 115.13 & 110.77 & 90.13 bcde & 105.34 \\
\hline 101 & 115.06 & 114.33 & 103.50 abcde & 110.96 \\
\hline 108 & 128.34 & 124.76 & 81.12 cde & 111.40 \\
\hline 125 & 124.36 & 119.65 & 93.08 bcde & 112.36 \\
\hline 133 & 116.44 & 111.16 & $66.80 \mathrm{e}$ & 98.14 \\
\hline 137 & 108.64 & 108.98 & $75.48 \mathrm{de}$ & 97.70 \\
\hline 138 & 113.34 & 124.87 & 81.22 cde & 106.48 \\
\hline 142 & 127.93 & 118.92 & 91.92 bcde & 112.92 \\
\hline Mean & 122.81 & 122.77 & 97.85 & 114.48 \\
\hline Standard deviation & 30.08 & 20.86 & 22.98 & 19.49 \\
\hline
\end{tabular}

Means followed by the same letter do not differ by the Tukey test at $5 \%$. 
In the first evaluation (autumn), there were statistical differences between progenies in the heartwood. Progeny 51 was the wettest and 138 the driest. Heartwood was wetter than the pith which, in turn, was wetter than the sapwood. Variations within progenies were similar according to standard deviation (Table 4). In the second evaluation, there was a statistical difference in sapwood between the progenies and in the mean. The sapwood was the driest and least variable compartment within the progenies (Table 5). In the third evaluation, there was a statistical difference in the heartwood and in the mean. Heartwood was the most humid compartment and sapwood the driest. The variability within progenies was also lower in the sapwood (Table 6). In the fourth evaluation, there was a statistical difference in the heartwood, which was the wettest compartment and with less variability (Table 7). In the fifth evaluation there was no statistical difference between the compartments (Table 8) and in the sixth evaluation there was a statistical difference in the sapwood, which was the least humid compartment (Table 9).

Table 10 - Correlation of wood moisture with Diameter at Breast Height (DBH) and Basic density (Bd) $\left(\mathrm{kgm}^{-3}\right)$ per season.

\begin{tabular}{ccc} 
Variable & Coefficient $\mathbf{r}$ & Probability $\mathbf{r}$ \\
\cline { 2 - 3 } & Average1 & 0.0153 \\
$\mathrm{DBH} 1$ & 0.3024 & 0.3989 \\
$\mathrm{Bb}$ & -0.1175 & \\
$\mathrm{DBH} 2$ & Total2 & 0.0350 \\
$\mathrm{Bb}$ & 0.2662 & 0.1601 \\
$\mathrm{DBH} 3$ & -0.1791 & 0.6787 \\
$\mathrm{Bb}$ & Total3 & 0.2138 \\
$\mathrm{DBH} 4$ & 0.0532 & \\
$\mathrm{Bb}$ & -0.1588 & 0.359 \\
$\mathrm{DBH} 5$ & Total4 & 0.2264 \\
$\mathrm{Bb}$ & 0.1176 & \\
$\mathrm{DBH} 6$ & -0.1546 & 0.6618 \\
$\mathrm{Bb}$ & Total5 & \\
\hline
\end{tabular}

There is no correlation of wood humidity with DBH or basic density, but in the drier seasons (autumn and winter) there were weak correlations between DBH and wood humidity, probably reflecting the consumption of elastic water (Table 10).

The volume of water in elastic storage is small because eucalypt species have only $18 \%$ rays. In eucalypts, the contraction and expansion of the xylem and phloem are diametrically opposite. When the phloem contracts during the day, the radius increases. In xylem, variation is low (base: $37.6 \mu \mathrm{m}$ and upper stem: $38.5 \mu \mathrm{m}$ ) compared to phloem (base: $212.1 \mu \mathrm{m}$; upper stem: $225.4 \mu \mathrm{m}$ ). Non-functional carbohydrates are stored in the rays. As wood humidity decreases, water and carbohydrates are extracted from the phloem into the sapwood rays. As water enters the vessels, carbohydrates accumulate in the rays, increasing the osmotic potential of the rays, which will result in an influx of water, hence the expansion of the sapwood. Once wood moisture is restored, usually at night, carbohydrates and water are drawn back into the phloem (Barrichelo \& Brito, 1976; Knipfer et al., 2019; Pfautsch et al., 2015; Pratt \& Jacobsen, 2017; Zeppel et al., 2019).

Basic density is negatively related to wood humidity, as the higher the basic density, the greater the amount of mass in the same volume of wood and, consequently, less space for free water to be stored (Table 10). 
The humidity in wood suffers considerable environmental influence as it is an ecological adaptation to climatic conditions. Anisohydric species, such as $E$. urophylla, suffer less fluctuations in water supply in the dry season or the rainy season than isohydric species because they store water in the stem (Knipfer et al., 2019; Pfautsch et al., 2015; Yi et al., 2017).

Ananías et al. (2014), studying with E. nitens at 17 years of age, found higher natural wood moisture in the pith (180\%) than in the heartwood (147\%) and sapwood (146\%). Similar results were found by Hillis (1978) with other eucalypts species. The wood's natural humidity can vary in different parts of the stem, but the variation between the different seasons of the year is negligible (Kollmann \& Côté Junior, 1984).

\section{CONCLUSION}

The storage of water in the stem of $E$. urophylla allows it to maintain the same growth rate at any time of the year, regardless of rainfall. There is no correlation between the diameter of the progenies with wood or soil humidity. There was no correlation between soil humidity and planting density or gap size.

\section{REFERENCES}

Ananías, R. A., Sepúlveda-Villarroel, V., Pérez-Peña, N., Leandro-Zuñiga, L., Salvo-Sepúlveda, L., SalinasLira, C., Cloutier, A., \& Elustondo, D. M. (2014). Collapse of Eucalyptus nitens wood after drying depending on the radial location within the stem. Drying Technology, 32(14), 1699-1705. http://dx.doi.org/10.1080/07373937.2014.924132.

Barrichelo, L. E. G., \& Brito, J. O. (1976). A madeira das espécies de eucalipto como matéria-prima para a indústria de celulose e papel (PRODEPEF - Projeto de Desenvolvimento e Pesquisa Florestal, No. 13, 145 p.). Brasília: PRODEPEF/PNUD/FAO/IBDF/BRA.

Bourne, A. E., Creek, D., Peters, J. M. R., Ellsworth, D. S., \& Choat, B. (2017). Species climate range influences hydraulic and stomatal traits in Eucalyptus species. Annals of Botany, 120(1), 123-133. PMid:28369162. http://dx.doi.org/10.1093/aob/mcx020

Empresa Brasileira de Pesquisa Agropecuária - Embrapa. (2018). Sistema Brasileiro de Classificação de Solos (5. ed.). Viçosa.

Hao, G. Y., Wheeler, J. K., Holbrook, N. M., \& Goldstein, G. (2013). Investigating xylem embolism formation, refilling and water storage in tree trunks using frequency domain reflectometry. Journal of Experimental Botany, 64(8), 2321-2332. PMid:23585669. http://dx.doi.org/10.1093/jxb/ert090.

Hillis, W. E. (1978). Wood quality and utilization. In W. E. Hillis \& A. G. Brown (Eds.), Eucalypts for wood production (pp. 259-289). Australia: CSIRO.

Indústria Brasileira de Árvores - IBA. (2020). Relatório anual 2020 (66 p.). Retrieved in 2021, March 12, from https://iba.org/datafiles/publicacoes/relatorios/relatorio-iba-2020.pdf

Knipfer, T., Reyes, C., Earles, J. M., Berry, Z. C., Johnson, D. M., Brodersen, C. R., \& McElrone, A. J. (2019). Spatiotemporal coupling of vessel cavitation and discharge of stored xylem water in a tree sapling. Plant Physiology, 179(4), 1658-1668. PMid:30718351. http://dx.doi.org/10.1104/pp.18.01303.

Kollmann, F. F. P., \& Côté Junior, W. (1984). Principles of wood science and technology I. Solid wood. BerlinHeidelberg, New York: Springer-Verlag.

Liu, W., Wu, J., Fan, H., Duan, H., Li, Q., Yuan, Y., \& Zhang, H. (2017). Estimations of evapotranspiration in an age sequence of Eucalyptus plantations in subtropical China. PLoS One, 12(4), e0174208. http://dx.doi.org/10.1371/journal.pone.0174208.

Magalhães, W. A., Freddi, O. S., Wruck, F. J., Petter, F. A., \& Tavanti, R. F. R. (2018). Soil water retention curve and $S$ index as soil physical quality indicators for integrated production systems. Engenharia Agrícola, 38(1), 64-73. http://dx.doi.org/10.1590/1809-4430-eng.agric.v38n1p64-73/2018.

Melo Neto, J. O., Mello, C. R., Silva, A. M., Mello, J. M., Viola, M. R., \& Yanagi, N. M. (2017). Temporal stability of soil moisture under effect of three spacings in an eucalypt stand. Acta Scientiarum. Agronomy, 39(3), 393-399. http://dx.doi.org/10.4025/actasciagron.v39i3.32656.

Payn, T., Carnus, J.-M., Freer-Smith, P., Kimberley, M., Kollert, W., Liu, S., Orazio, C., Rodriguez, L., Silva, L. N., \& Wingfield, M. J. (2015). Changes in planted forests and future global implications. Forest Ecology and Management, 352, 57-67. 
Pfautsch, S., Holtta, T., \& Mencuccini, M. (2015). Hydraulic Functioning of tree stems: fusing ray anatomy, radial transfer and capacitance. Tree Physiology, 35(7), 706-722. http://dx.doi.org/10.1093/treephys/tpv058.

Pratt, R. B., \& Jacobsen, A. L. (2017). Conflucting demands on angiosperm xylem: tradoffs among storage, transport and biomechanics. Plant, Cell \& Environment, 40(6), 897-913. http://dx.doi.org/10.1111/pce.12862.

Pryor, L. D., Williams, E. R., \& Gunn, B. V. (1995). A morphometric analysis of Eucalyptus urophylla and related taxa with descriptions of two new species. Australian Systematic Botany, 8(1), 57-70.

Scanavaca Júnior, L., \& Garcia, J. N. (2021). Eucalyptus subgenus Symphyomyrtus: sections: Exsertaria, Latoangulatae and Maidenaria. Scientia Agrícola, 78(Suppl. 1), e20200173. http://dx.doi.org/10.1590/1678-992x-2020-0173.

Universidade de São Paulo - USP. Escola Superior de Agricultura "Luiz de Queiroz" - ESALQ. Estação Experimental de Ciências Florestais de Anhembi. (2020). Mapa/características. Retrieved in 2020, December 7, from https://www.esalq.usp.br/svee/lcf-anhembi/mapa-caracteristicas

Yi, K., Dragoni, D., Phillips, R. P., Roman, D. T., \& Novick, K. A. (2017). Dynamics of stem water uptake among isohydric and anisohydric species experiencing a severe drought. Tree Physiology, 37(10), 1393. http://dx.doi.org/10.1093/treephys/tpx014.

Zeppel, M. J. B., Anderegg, W. R. L., Adams, H. D., Hudson, P., Cook, A., Rumman, R., Eamus, D., Tissue, D. T., \& Pacala, S. W. (2019). Embolism recovery strategies and nocturnal water loss across species influenced by biogeographic origin. Ecology and Evolution, 9(9), 5348-5361.

Zhang, Z., Zhao, P., McCarthy, H. R., Ouyang, L., Niu, J., Zhu, L., Ni, G., \& Huang, Y. (2016). Hydraulic balance of a Eucalyptus urophylla plantation in response to periodic drought in subtropical China. Frontiers of Plant Science, 7(26), http://dx.doi.org/10.3389/fpls.2016.01346.

Zweifel, R., Steppe, K., \& Sterck, F. J. (2007). Stomatal regulation by microclimate and tree water relations: interpreting ecophysiological field data with a hydraulic plant model. Journal of Experimental Botany, 58(8), 2113-2131. http://dx.doi.org/10.1093/jxb/erm050.

Author's contributions: LSJ: Conceptualization, data curation, formal analysis, methodology, supervision, writing; JNG: Conceptualization. 